\title{
UPAYA PELESTARIAN KEARIFAN LOKAL MELALUI EKSTRAKURIKULER KARAWITAN DI SMP NEGERI 1 JIWAN TAHUN 2016
}

\author{
Pryo Sularso, Yuli Maria \\ Universitas PGRI Madiun \\ email: pryosularso@unipma.ac.id
}

Naskah diterima: 25/04/2017 revisi: 27/04/2017 disetujui: 27/04/2017

\begin{abstract}
Abstrak
Tujuan penelitian ini adalah untuk mendeskripsikan dan menganalisis pelaksanaan ekstrakurikuler karawitan di SMP Negeri 1 Jiwan dapat digunakan sebagai sarana pelestarian kearifan lokal. Subjek penelitian ini adalah para siswa peserta ekstrakurikuler karawita dan Bapak/Ibu Guru Pembina ekstrakurikuler karawitan. Penelitian ini membuktikan bahwa ekstrakurikuler karawitan dapat dijadikan sebagai sarana pelestarian nilai-nilai kearifan lokal karena dalam pelaksanaannya terjadi transfer nilai-nilai kearifan lokal dari Bapak/Ibu Guru kepada para siswa peserta ekstrakurikuler karawitan. Para siswa yang mengikuti kegiatan ekstrakurikuler karawitan memahami nilai-nilai kearifan lokal yang tersimpan dalam alat musik, gending, tembang ataupun tarian yang menjadi bagian dari karawitan tersebut serta mengimplementasikannya dalam kehidupan sehari-hari.
\end{abstract}

Kata kunci: Kearifan Lokal, Ekstrakurikuler, Karawitan

\section{CONSERVATION EFFORTS THROUGH LOCAL WISDOM IN EXTRACURRICULAR KARAWITAN SMP NEGERI 1 JIWAN YEAR 2016 \\ Abstract}

The purpose of this study is to describe and analyze the implementation of extracurricular musical SMP Negeri 1 Jiwan can be used as a means of preservation of local wisdom. The subjects were students extracurricular participants karawita and Mr / Ms Guru Pembina extracurricular musical. This study proves that the extra-musical can be used as a means of preserving the values of local wisdom for the implementation of a transfer of the values of local wisdom of teacher to the students musical extracurricular participants. The students who participated in extracurricular musical understand the local wisdom values stored in the instrument, the musical, song or dance that became part of the musical and implement them in everyday life.

Keywords: Local Wisdom, Extracurricular, Karawitan 
Citizenship Jurnal Pendidikan Pancasila dan Kewarganegaraan Vol 5 No 1 April 2o17, hal 1-12 Avaliable online at : http://e-journal.unipma.ac.id/index.php/citizenship

p-ISSN: 2302-433Xp e-ISSN 2579-5740

\section{PENDAHULUAN}

Saat ini semua bangsa sedang berada di tengah era globalisasi. Perkembangan budaya modern yang berciri khas budaya barat masuk dan mempengaruhi segala aspek kehidupan masyarakat, baik itu di bidang politik, ekonomi, teknologi informasi, sosial, budaya dan seni. Hal tersebut tentunya akan membawa dampak positif maupun dampak negatif dalam berbagai bidang. Nilai-nilai budaya barat dengan mudahnya masuk melalui berbagai media informasi yang kadang-kadang ditiru habis-habisan terutama oleh para remaja atau generasi muda Indonesia.

Kalangan generasi muda Indonesia ini salah satunya adalah anak-anak yang masih duduk di bangku sekolah menengah pertama (SMP). Kalangan generasi muda ini adalah kalangan yang masih labil dan belum bisa dengan bijaksana memilih dan memilah antara pengaruh yang baik dan pengaruh yang tidak baik. Semua hal yang dianggap kekinian dan sedang menjadi trend diikuti. Padahal tidak semua hal tersebut positif. Hal tersebut terjadi juga pada kalangan siswa di SMP Negeri 1 Jiwan. Kalangan siswa di SMP Negeri 1 Jiwan memperlihatkan ketertarikan mereka pada gaya budaya barat. Selain itu seni yang mereka pilih dan mereka minati adalah seni dari barat. Mereka mengikuti segala sesuatu hal yang berhubungan dengan budaya barat, baik itu cara berpakaian, model rambut dan mereka juga tertarik sekali pada musik dan film dari barat. Hal ini tidak mengkhawatirkan bila generasi muda tidak melupakan budaya lokal meskipun tertarik pada budaya barat. Berangkat dari pemikiran inilah dirasa mulai timbul masalah karena antara yang diharapkan dan kenyataan yang terjadi itu tidak sesuai. Harapannya adalah anak muda Indonesia pada umumnya dan kalangan siswa di SMP Negeri 1 Jiwan pada khususnya mau mempelajari dan melestarikan seni budaya lokal meski mereka tertarik pada budaya barat. Kenyataannya tidak seperti itu, kalangan generasi muda tersebut justru enggan untuk mempelajari budaya lokal karena dianggap tidak menarik dan tidak kekinian. Padahal budaya lokal tidak kalah menarik dengan budaya barat. Budaya lokal justru memiliki keunggulan, yaitu selain bernilai estetis tinggi, budaya lokal tersebut mengandung nilai-nilai kearifan lokal yang baik digunakan sebagai pedoman dalam kehidupan. Bila seni budaya lokalnya saja dilupakan maka nilai-nilai kearifan lokalnyapun juga akan dilupakan dan hilang dimakan zaman.

Berkaitan dengan hal tersebut, maka SMP Negeri 1 Jiwan sebagai sebuah lembaga pendidikan berusaha untuk melaksanakan fungsi dan tujuan pendidikan yaitu sesuai yang tercantum dalam UU No. 20 Tahun 2013 tentang Sisdiknas yaitu sebagai berikut.

Pendidikan nasional berfungsi mengembangkan kemampuan dan membentuk watak serta peradaban bangsa yang bermartabat dalam rangka mencerdaskan kehidupan bangsa, bertujuan untuk berkembangnya potensi peserta didik agar menjadi Manusia yang beriman dan bertakwa kepada Tuhan Yang Maha Esa, berakhlak mulia, sehat, berilmu, cakap, kreatif, mandiri, dan menjadi warga negara yang demokratis serta bertanggung jawab.

Pengembangan potensi peserta didik sebagaimana dimaksud dalam tujuan Pendidikan Nasional tersebut dapat diwujudkan melalui kegiatan ekstrakurikuler. Wahjosumidjo (dalam Kompri 2015: 225) mendefinisikan kegiatan ekstrakurikuler sebagai berikut.

Kegiatan ekstrakurikuler adalah kegiatan-kegiatan siswa di luar jam pelajaran yang dilaksanakan di sekolah atau di luar sekolah dengan tujuan untuk memperluas pengetahuan, memahami

\section{2 | Pryo Sularso, Yuli Maria Upaya Pelestarian Kearifan Lokal Melalui Ekstrakurikuler Karawitan di SMP Negeri 1 Jiwan Tahun 2016}


Citizenship Jurnal Pendidikan Pancasila dan Kewarganegaraan Vol 5 No 1 April 2017, hal 1-12 Avaliable online at : http://e-journal.unipma.ac.id/index.php/citizenship

p-ISSN: 2302-433Xp e-ISSN 2579-5740

keterkaitan antar berbagai mata pelajaran, penyaluran bakat dan minat dan dalam rangka usaha untuk meningkatkan kualitas keimanan dan ketakwaan kepada Tuhan Yang Maha Esa, kesadaran berbangsa dan bernegara, berbudi pekerti luhur dan sebagainya.

Dari pernyataan tersebut dapat dipahami bahwa kegiatan ekstrakurikuler berperan dalam pengembangan bakat, minat dan potensi peserta didik serta berperan dalam perkembangan diri peserta didik dalam hal pemahaman terhadap nilai-nilai nasional, moral, sosial dan spiritual. Berkaitan dengan hal tersebut, SMP Negeri 1 Jiwan memiliki alasan yang kuat untuk menjadikan karawitan sebagai salah satu kegiatan ekstrakurikuler di sekolah. Harapan sekolah melaksanakan kegiatan ekstrakurikuler karawitan ini adalah untuk mengembangkan karakter cinta budaya lokal dan untuk melestarikan nilai-nilai kearifan lokal yang terdapat dalam karawitan. Hal ini sesuai dengan pendidikan berbasis keunggulan lokal yang diselenggarakan oleh SMP Negeri 1 Jiwan. Pendidikan berbasis keunggulan lokal ini dilaksanakan melalui penanaman nilai-nilai kearifan lokal

dengan jalan pelestarian kesenian tradisional yang mana salah satu bentuknya adalah melalui ekstrakurikuler karawitan. Maka dari hal itulah penulis tertarik melakukan penelitian dengan judul "Upaya Pelestarian Kearifan Lokal Melalui Ekstrakurikuler Karawitan Di SMP Negeri 1 Jiwan Tahun 2016".

\section{METODE}

\section{Jenis Penelitian}

Penelitian menggunakan pendekatan deskriptif kualitatif.

\section{Waktu dan Tempat Penelitian}

Penelitian di lakukan di SMP Negeri 1 Jiwan Kabupaten Madiun dan dilaksanakan pada bulan Februari sampai dengan Juli 2016.

\section{Target/Subjek Penelitian}

Subjek penelitian ini adalah para siswa peserta ekstrakurikuler karawitan dan bapak/ibu guru pembina ekstrakurikuler karawitan. Sumber data ditentukan dengan teknik purposive sampling. Teknik pengumpulan data yang digunakan penulis yakni dengan melakukan wawancara, observasi dan dokumentasi.

\section{Prosedur}

Data yang di dapatkan kemuian dianalisis dengan cara reduksi data yakni memilah data yang digunakan dan tidak, setelah itu dilanjutkan penyajian data yakni menampilkan data-data yang telah di analisis dan penarikan kesimpulan yakni menyimpulkan hasil analisis data.

\section{Teknik Analisis Data}

Sedangkan teknik analisis data yang digunakan adalah metode dekriptif dengan analisis kualitatif dan jenis penelitian fenomenologi.

\section{HASIL DAN PEMBAHASAN}

Suhartini (dalam Wibowo dan Gunawan, 2015: 17) menyatakan bahwa kearifan lokal adalah sebuah warisan nenek moyang yang berkaitan dengan tata nilai kehidupan. Dari pernyataan tersebut dapat dipahami bahwa kearifan lokal bisa berwujud atau berbentuk nilai-nilai yang tidak nampak namun diyakini dan dilaksanakan oleh suatu kelompok masyarakat tertentu. Dari pernyataan tersebut terdapat kata warisan, yang mana artinya kearifan lokal adalah sesuatu yang akan terus diwariskan atau diturunkan kepada para generasi berikutnya. Berkaitan dengan hal tersebut, tulisan ini mencoba membahas cara atau sarana yang bisa digunakan untuk mewariskan nilai-nilai kearifan lokal kepada generasi muda. Salah 
Citizenship Jurnal Pendidikan Pancasila dan Kewarganegaraan Vol 5 No 1 April 2017, hal 1-12 Avaliable online at : http://e-journal.unipma.ac.id/index.php/citizenship

p-ISSN: 2302-433Xp e-ISSN 2579-5740

satu cara strategis yang bisa ditempuh untuk mewariskan dan melestarikan nilai-nilai kearifan lokal adalah dengan melalui ekstrakurikuler karawitan yang diadakan oleh SMP Negeri 1 Jiwan.

\section{Pelaksanaan Ekstrakurikuler Karawitan Di SMP Negeri 1 Jiwan}

Kegiatan ekstrakurikuler di SMP Negeri 1 Jiwan dilaksanakan setiap hari Jumat. Untuk bisa mengikuti kegiatan ekstrakurikuler tersebut maka siswa harus mendaftarkan diri saat ada proses perekrutan anggota ekstrakurikuler karawitan yang dilaksanakan setiap awal tahun pelajaran. Cara perekrutan siswa di SMP Negeri 1 Jiwan untuk menjadi anggota ekstrakurikuler karawitan dilakukan berdasarkan kesadaran pribadi siswa bukan karena paksaan dari pihak manapun.

Berdasarkan hasil wawancara yang dilakukan dengan Bapak/Ibu Guru Pembina Ekstrakurikuler Karawitan

di SMP Negeri 1 Jiwan didapatkan data bahwa dalam proses perekrutan siswa menjadi anggota ekstrakurikuler karawitan tidak ada unsur paksaan, semua atas dasar kesadaran dan keinginan pribadi siswa sendiri untuk masuk menjadi anggota ekstrakurikuler karawitan. Hal tersebut sesuai dengan pernyataan Rohinah (2012: 94) bahwa "kegiatan ekskul adalah kegiatan non kurikuler yang diadakan oleh sekolah untuk menyalurkan minat dan bakat peserta didik sesuai dengan pilihan yang disukainya". Jadi, pada hakikatnya kegiatan ekstrakurikuler yang diikuti siswa adalah kegiatan ekstrakurikuler yang disukai siswa dan sesuai dengan minat atau potensi siswa.

Berkaitan dengan hal tersebut bila siswa mengikuti kegiatan ekstrakurikuler sesuai kesadaran maka otomatis siswa akan aktif dalam mengikuti kegiatan tersebut mengingat banyak kegiatan ekstrakurikuler lain yang dapat diikuti selain ekstrakurikuler karawitan. Pemikiran tersebut sesuai dengan hasil wawancara yang dilakukan dengan para siswa peserta ekstrakurikuler karawitan. Para siswa mengakui bahwa mereka terlibat aktif dalam kegiatan ekstrakurikuler karawitan karena memang dari awal mereka berniat untuk mengikuti kegiatan tersebut, baik dengan tujuan mengembangkan bakat minat ataupun karena keinginan para siswa untuk ikut melestarikan kesenian tradisional karawitan.

Berdasarkan hasil wawancara yang dilakukan dengan para guru pembina ekstrakurikuler karawitan, didapatkan data bahwa alasan sekolah menjadikan karawitan sebagai salah satu kegiatan ekstrakurikuler adalah pertama, sekolah ingin mewadahi bakat, minat dan potensi yang dimiliki oleh siswa sehingga siswa dapat mengembangkan minat dan bakat yang ada dalam diri siswa terhadap kebudayaan daerah sendiri. Kedua untuk meningkatkan kesadaran siswa dalam upaya pelestarian kebudayaan daerah. Ketiga untuk menanamkan kesadaran siswa agar lebih mengenal dan mencintai kebudayaan daerahnya sendiri. Keempat, untuk membentuk siswa yang beakhlak mulia, berbudi luhur dan menjaga etika kebudayaan daerah.

Ekstrakurikuler karawitan yang dilaksanakan oleh SMP Negeri 1 Jiwan tidak semata-mata untuk mengembangkan bakat, minat atau potensi siswa saja. Namun melalui ekstrakurikuler karawitan, sekolah ingin menanamkan karakter cinta tanah air pada siswa, meningkatan kesadaran diri siswa pada kebudayaan lokal. Selain itu sekolah juga menjadikan ekstrakurikuler karawitan sebagai salah satu sarana untuk melestarikan kearifan lokal mengingat karawitan adalah salah satu wujud kebudayaan Jawa yang mana penciptaan karawitan tersebut tidak hanya untuk memenuhi unsur keindahan semata namun untuk menyampaikan nilai-nilai luhur kepada masyarakat.

Berkaitan dengan keikutsertaan siswa dalam ekstrakurikuler karawitan dari hasil 
Citizenship Jurnal Pendidikan Pancasila dan Kewarganegaraan Vol 5 No 1 April 2017, hal 1-12

Avaliable online at : http://e-journal.unipma.ac.id/index.php/citizenship

p-ISSN: 2302-433Xp e-ISSN 2579-5740

wawancara didapatkan data bahwa alasan keikutsertaan para siswa dalam kegiatan ekstrakurikuler karawitan adalah karena ingin mengembangkan bakat, minat dan potensi yang ada dalam diri siswa. Pada dasarnya siswa yang mengikuti ekstrakurikuler karawitan sudah mengetahui bakat yang mereka miliki. Kebanyakan para siswa menyatakan bahwa sejak di jenjang sekolah dasar para siswa telah mengikuti kegiatan ekstrakurikuler karawitan sehingga pada akhirnya bakat yang telah dimiliki tersebut ingin lebih dikembangkan lagi dengan mengikuti kegiatan ekstrakurikuler yang sama di jenjang SMP. Selain untuk mengembangkan bakat, minat atau potensi yang dimiliki siswa dalam bidang seni, alasan lain keterlibatan siswa dalam mengikuti ekstrakurikuler karawitan adalah karena para siswa ingin melestarikan kebudayaan tradisional Jawa atau kebudayaan lokal.

Keikutsertaan siswa dalam kegiatan ekstrakurikuler karawitan ini tidak terlepas dari dukungan orang tua. Berdasarkan hasil wawancara dengan siswa dan guru pembina ekstrakurikuler karawitan didapatkan data bahwa semua orang tua siswa mendukung keterlibatan siswa dalam kegiatan ekstrakurikuler karawitan. Hal ini karena pada dasarnya para orang tua siswa sudah mengetahui bakat dan potensi anak-anak mereka. Sehingga orang tua selalu mendukung keikutsertaan siswa dalam kegiatan ekstrakurikuler karawitan. Beberapa siswa juga menyatakan bahwa orang tua memberikan dukungan karena orang tua menginginkan anak-anak mereka ikut serta dalam melestarikan kebudayaan daerah atau kebudayaan tradisional sehingga kelak dapat diwariskan kepada anak cucu atau generasi berikutnya.

\section{Nilai-nilai Kearifan Lokal yang} Tersimpan dalam Alat Musik Karawitan

Karawitan adalah salah satu bentuk budaya manusia dari segi rasa yang mana tujuan pembuatannya adalah untuk pemenuhan kebutuhan manusia akan rasa keindahan dan sebagai salah satu media penyampaian makna atau nilai-nilai luhur kepada masyarakat secara halus. Dari hasil wawancara dengan Bapak/Ibu Guru pembina ekstrakurikuler karawitan didapatkan data bahwa dalam kegiatan ekstrakurikuler karawitan tidak hanya sekedar diajarkan bagaimana cara memainkan alat musik karawitan semata, namun juga ada transfer nilai atau makna yang terkandung dalam seni karawitan tersebut.

Berkaitan dengan alat musik karawitan yang dimainkan oleh para siswa ternyata setiap alat musik tersebut tidak hanya sekedar alat musik yang menghasilkan suara indah namun setiap nama dari alat musik tersebut mengandung filosofi mendalam dan bermakna. Berdasarkan hasil wawancara dengan para siswa, didapatkan data bahwa para siswa memahami makna atau nilai yang terkandung dalam alat musik karawitan yang dimainkannya. Mereka mengakui bahwa makna atau nilai tersebut diketahui dari Bapak/Ibu Guru.

Setiap alat musik dalam karawitan tersebut tidak hanya sekedar alat musik yang dipukul untuk menghasilkan suara yang indah. Alat musik dalam karawitan tersebut memiliki makna atau nilai-nilai luhur. Makna atau nilai-nilai luhur tersebut diambil dari filosofi nama dan bunyi yang dihasilkan dari masing-masing alat musik karawitan. Berdasarkan hasil wawancara didapatkan data bahwa setiap nama alat musik yang menjadi bagian dari karawitan memiliki arti atau makna yang dapat dijadikan sebagai pedoman dalam kehidupan. Misalnya alat musik Gong, dari hasil wawancara didapatkan data bahwa nama gong memiliki filosofi Allah Yang Maha Besar. Dari filosofi tersebut terdapat nilai spiritual yaitu segala sesuatu bisa terjadi atas ijin dari Allah. Hal tersebut tentu akan selalu 
Citizenship Jurnal Pendidikan Pancasila dan Kewarganegaraan Vol 5 No 1 April 2017, hal 1-12 Avaliable online at : http://e-journal.unipma.ac.id/index.php/citizenship

p-ISSN: 2302-433Xp e-ISSN 2579-5740

mengingatkan manusia akan kebesaran Allah dan mengajak manusia untuk selalu berpasrah kepada Allah. Selain itu bunyi yang dihasilkan dari alat musik karawitan juga memiliki makna atau nilai. Misalnya bunyi yang dihasilkan oleh gong, berbunyi "gong", bunyi ini memiliki arti "agong" atau agung yang artinya besar. Filosofi dari bunyi yang dihasilkan gong ini adalah simbolisasi dari keberadaan Tuhan Yang Maha Besar. Mendengar bunyi gong biasanya hati akan bergetar maka diharapkan manusia senantiasa selalu ingat akan kebesaran Tuhan dan bermunajat kepada Tuhan.

Selain alat musik gong, dari hasil wawancara, didapatkan pula data bahwa alat musik lain seperti kenong, gender, bonang, rebab, demung, kendhang dan lainnya juga memiliki nilai atau filosofi masing-masing. Semua perangkat alat musik karawitan menyimpan nilai atau makna masingmasing. Alat musik selain gong, misalnya Bonang memiliki makna kemenangan melawan hawa nafsu. Jadi dari alat musik bonang tersebut para pemain karawitan dapat belajar tentang nilai moral, yang mana sebagai manusia dapat dikatakan telah memperoleh kemenangan sejati apabila manusia tersebut telah menang melawan hawa nafsu diri sendiri. Tidak hanya berhenti pada gong dan kendhang saja, namun alat musik yang lain juga memiliki nilai-nilai kearifan lokal masing-masing yang dapat digunakan sebagai pedoman dalam kehidupan.

$\begin{array}{llcr}\text { Nilai-nilai } & \begin{array}{c}\text { Kearifan } \\ \text { dalam }\end{array} & \begin{array}{c}\text { Lokal } \\ \text { Tembimpang } \\ \text { Gendhing }\end{array} & \begin{array}{r}\text { yang } \\ \text { dan }\end{array} \\ & & & \end{array}$

Selain alat musik karawitan, yang menjadi unsur penting adalah tembang dan gendhing. Tembang dan gendhing tidak hanya sekedar lagu atau irama yang indah untuk didengar namun di dalam lirik atau syair tembang dan gendhing tersebut terdapat makna atau nilai-nilai kearifan lokal yang ingin disampaikan ke siswa. Baik itu tembang dari jenis macapat, dolanan, maupun campursari. Ketiganya memiliki nilai-nilai yang ingin disampaikan kepada para pendengar. Berdasarkan hasil wawancara didapatkan data bahwa sejauh ini para siswa dapat menangkap makna atau nilai yang terkandung dalam tembang dan gendhing yang diajarkan dalam ekstrakurikuler karawitan. Jenis tembang yang dipelajari misalnya tembang macapat. Bapak/Ibu Guru pembina ekstrakurikuler karawitan menyebutkan bahwa tembang macapat terdiri dari 11 tembang yaitu : maskumambang, mijil, sinom, kinanthi, asmaradhana, gambuh, dandhanggula, durma, pangkur, megatruh, dan pocung. Kesebelas tembang macapat tersebut masing-masing memiliki makna tersendiri yang bila dipelajari secara sungguh-sungguh akan ada banyak nilai-nilai kehidupan yang bisa dipetik. Pada dasarnya mulai dari tembang maskumambang sampai dengan tembang pocung memang tidak hanya sekedar tembang yang dinikmati keindahannya saat dinyanyikan, namun dalam lirik atau syairnya terdapat makna atau arti yang mendalam yang dapat digunakan sebagai pedoman dalam kehidupan.

Bapak/ibu guru dan siswa peserta ekstrakurikuler karawitan menyebutkan bahwa selain tembang macapat, ada pula tembang dolanan. Tembang dolanan adalah tembang Jawa yang sering dinyanyikan anak-anak jaman dahulu saat bermain dengan teman-temannya. Tembang dolanan tersebut misalnya gundul-gundul pacul, cublak-cublak suweng, sluku-sluku batok, jamuran, padhang bulan, ilir-ilir, dan lain sebagainya. Menurut Bapak/Ibu Guru pembina ekstrakurikuler karawitan menyatakan bahwa tembang dolanan tersebut tidak hanya sekedar tembang yang dinyanyikan anak-anak saat dolanan, tembang dolanan ini memiliki makna dan nilai-nilai kearifan lokal yang mendalam 
Citizenship Jurnal Pendidikan Pancasila dan Kewarganegaraan Vol 5 No 1 April 2017, hal 1-12 Avaliable online at : http://e-journal.unipma.ac.id/index.php/citizenship

p-ISSN: 2302-433Xp e-ISSN 2579-5740

seperti tembang macapat. Banyak nilai-nilai moral, sosial dan spiritual yang ingin disampaikan kepada anak-anak lewat lagu dolanan yang sejarahnya dahulu adalah tembang ciptaan para sunan untuk berdakwah agama islam. Selain tembang, adapula gendhing yang dipelajari. Perbedaan antara tembang dan gendhing adalah terletak pada keharusan ada tidaknya musik yang mengiringi. Tembang mengutamakan suara vokal manusia, bisa diiringi musik ataupun tidak. Sedangkan gendhing mengutamakan musik untuk mengiringi lirik atau syair lagu yang dinyanyikan. Contoh gendhing adalah Sri Wilujeng, Sri Widodo, Mugi Rahayu, Sri Rejeki, Puspawarno dan lain-lain.

Dari hasil wawancara didapatkan data bahwa tembang yang sering dipelajari di SMP Negeri 1 Jiwan adalah tembang macapat, tembang dolanan dan tembang campursari. Tembang macapat terdiri dari sebelas tembang dimana urut-urutan tembang macapat tersebut menceritakan kisah hidup manusia di dunia ini. Pernyataan tersebut sesuai dengan pernyataan yang diungkapkan oleh Heliarta (2009: 29) yang menyatakan bahwa "urutan tembang Jawa tersebut sama dengan perjalanan hidup manusia dari mulai bayi hingga meninggal”.

Tembang macapat berjudul Sinom, memiliki makna yang ingin disampaikan bahwa selagi masih muda dan banyak waktu hendaknya generasi muda memiliki semangat yang tinggi untuk belajar dan bekerja keras demi mencapai cita-cita. Pernyataan dari hasil wawancara tersebut sesuai dengan pernyataan yang disampaikan oleh Heliarta (2009: 34) yang menjelaskan bahwa "Sinom berarti "kanoman" (kemudaan/usia muda) yaitu waktu luang pada masa muda untuk menimba ilmu sebanyak-banyaknya".

Selain Sinom, dari hasil wawancara juga didapatkan data bahwa tembang Pangkur juga memiliki makna atau mengandung nilai-nilai kearifan lokal yang patut juga dijadikan sebagai pedoman dalam kehidupan. Dari hasil wawancara didapatkan data bahwa makna yang terdapat dalam tembang pangkur adalah tentang nilai-nilai moral yang mengajarkan kepada manusia untuk mengendalikan diri melawan hawa nafsu yang negatif. Pernyaataan tersebut sesuai dengan teori Bratawijaya (1997: 92) yang menyatakan bahwa "dalam syair Pangkur dimaksudkan agar seseorang dapat mengendalikan diri untuk dapat menangkal perbuatan jahat atau larangan-larangan untuk dilakukan". Hal ini juga selaras dengan pernyataan Heliarta (2009: 50) yang menyatakan bahwa "Pangkur berasal dari kata 'mungkur' (mundur) yang berarti sudah memundurkan semua hawa nafsunya".

\section{Nilai-nilai Kearifan Lokal yang Tersimpan dalam Tari Tradisional yang diiringi Karawitan}

Pada hakikatnya ada beragam seni yang bisa dipelajari melalui karawitan, misalnya seni tari. Di SMP Negeri 1 Jiwan, dalam pelaksanaan ekstrakurikuler karawitan sering digunakan untuk mengiringi tarian tradisional Jawa, misalnya tari jaranan, tari remong, tari dongkrek dan tari merak. Tarian tersebut diiringi suara musik dari sebagian atau seluruh alat musik karawitan Jawa. Sebagian di sini maksudnya hanya satu atau beberapa alat musik karawitan saja yang digunakan untuk mengiringi tarian tersebut.

Ekstrakurikuler karawitan di SMP Negeri 1 Jiwan tidak hanya sekedar mempelajari seni musik semata namun seni musik tersebut digunakan pula untuk mengiringi seni tari atau gerak. Seni tari yang dipelajari misalnya tari dongkrek yang merupakan tari khas daerah Madiun. Dalam tari dongkrek ini gamelan yang digunakan adalah bedug atau kendhang, korek, kentongan, kenong, gong besi, gong kempul dan kendang. Tari dongkrek ini menceritakan perjuangan masyarakat Mejayan dalam mengatasi pagebluk atau 
Citizenship Jurnal Pendidikan Pancasila dan Kewarganegaraan Vol 5 No 1 April 2017, hal 1-12 Avaliable online at : http://e-journal.unipma.ac.id/index.php/citizenship

p-ISSN: 2302-433Xp e-ISSN 2579-5740

musibah yang menyerang daerah Mejayan berupa penyakit. Menurut sejarah dinyatakan bahwa sang sesepuh bertapa untuk meminta petunjuk dari yang maha kuasa demi mencari jalan keluar untuk membebaskan masyarakat Mejayan dari musibah tersebut. Dari tarian tersebut dapat dipetik nilai spiritual atau religius yaitu dari gerakan bertapa yang diperankan oleh sesepuh yang melambangkan kepasrahan kepada Tuhan untuk meminta petunjuk jalan keluar dari masalah yang dihadapi.

Selain tari dongkrek, adapula tari remo yang dipelajari. Tari remo adalah tari khas Jawa Timur. Tari remo ini melambangkan kepahlawanan. Dalam tari remo ada banyak gerakan dan memiliki banyak filosofi atau nilai-nilai kearifan lokal yang mendalam yang dapat digunakan sebagai pedoman dalam kehidupan. Dalam tarian ini yang dominan adalah gerakan menghentak bumi atau nggedruk, gerakan ini memiliki arti mulainya manusia mengenal bumi yaitu diawali dengan lahirnya manusia di bumi, selanjutnya manusia mulai beradaptasi dengan bumi dan menyatu dengan bumi yang pada akhirnya ketika manusia sewaktuwaktu akan pergi ke perantauan manusia selalu memohon kepada Tuhan agar Tuhan memberkatinya di tanah atau tempat baru yang menjadi perantauannya. Kalau orang Jawa yang masih sangat kuno artinya masih percaya pada budaya dan adat saat akan berangkat ke perantauan ketika pertama kali melangkahkan kaki keluar dari rumah selalu mengucap "Nini among kaki among, sing ngemong ragaku sak benere, sing nyekseni awake dewe yoiku bapa rina ibu wengi. Awan golek sandang pangan yoiku bapakku, bengi wayah turu sing nyekseni ibuku dhewe". Kalimat ini memiliki makna kepasarahan manusia kepada Tuhan dan memohon perlindungan dari Tuhan apapun keadaannya. Selanjutnya dalam tari remo ada pula gerakan melempar sampur atau selendang ke arah luar hal ini memiliki arti menghalau hal-hal negatif atau mengindar hal-hal negatif. Adapula gerakan mengibaskan rambut ke arah luar atau dalam bahasa Jawa "ngore rekmo" gerakan ini memiliki arti merias diri dimana artinya seabagai manusia keindahan di luar itu penting namun keindahan dari dalam lebih penting artinya setiap manusia harus berusaha memiliki hati yang bersih, pikiran yang bersih dan selalu mengutamakan kebaikan sehingga kebaikannya terpancar ke luar.

Selain tari dongkrek dan tari remo adapula tari jaranan dan tari merak. Dalam tari jaranan ini ada penari yang menaiki sebuah kuda dua dimensi yang terbuat dari anyaman bambu. Penari dalam tarian ini menggambarkan manusia yang mengendarai kuda. Kuda adalah kendaraan manusia untuk mencapai tujun hidupnya di dunia ini. Maka dari itu penari jaranan merupakan gambaran dari sosok manusia yang sedang menempuh perjalanan hidup guna mencapai apa yang menjadi cita-cita, harapan atau tujuan hidupnya. Kemudian selain tokoh penari jaranan, ada pula penari dengan menggunakan topeng macan dan celeng. Penari dengan topeng macan (harimau) dan topeng celeng (babi hutan) ini menggambarkan gangguan atau cobaan atau energi negatif yang mencoba untuk menggagalkan usaha manusia dalam mencapai tujuannya. Maka dari itu dalam tarian ini penari macan dan celeng seakanakan menghadang atau mengganggu penari jaranan. Kemudian sang penari jaranan menggerak-gerakan cambuk atau pecut yang dibawanya, gerakan ini menggambarkan halauan atau perlawanan terhadap energi negatif atau terhadap gangguan dari macan dan celeng tersebut. Makna yang ingin disampaikan adalah manusia hendaknya memiliki kesungguhan dalam berusaha mencapai tujuannya. Meskipun banyak halangan, hendaknya manusia tidak boleh menyerah dan berputus asa. Tari merak 
Citizenship Jurnal Pendidikan Pancasila dan Kewarganegaraan Vol 5 No 1 April 2017, hal 1-12 Avaliable online at : http://e-journal.unipma.ac.id/index.php/citizenship

p-ISSN: 2302-433Xp e-ISSN 2579-5740

adalah sebuah tarian yang menggambarkan binatang merak dengan keindahan bulu yang dimilikinya. Tari merak ini membawa suasana yang penuh sukacita. Biasanya dalam tari merak ini sang penari memakai kostum dengan warna-warna cerah sehingga suasana menjadi lebih semarak. Tari merak ini memiliki makna yaitu hendaknya kita berbagi kebaikan, hal-hal positif, sukacita dan rejeki kepada orang lain sehingga orang lain juga bisa merasakan sukacita pula seperti yang kita rasakan.

\section{SIMPULAN DAN SARAN}

\section{Simpulan}

Berdasarkan pembahasan tersebut dapat diambil kesimpulan bahwa setiap tarian tradisional yang diiringi oleh gamelan tersebut ternyata memiliki nilai-nilai kearifan lokal yang mendalam. Nilai- nilai kearifan lokal tersebut bisa dipetik dari gerakan dalam tarian tersebut, sejarah tarian tersebut, alat-alat peraga dalam tarian tersebut dan masih banyak lagi. Pada intinya, seni tari tradisional yang merupakan bagian dari kebudayaan lokal tersebut tidak hanya sekedar dapat dinikmati nilai-nilai estetikanya saja, namun dari tarian tersebut juga bisa dipetik nilai-nilai spiritual, moral dan sosial.

Dengan mengetahui gambaran mengenai upaya pelestarian kearifan lokal melalui ekstrakurikuler karawitan di SMP Negeri 1 Jiwan maka peneliti dapat memberikan saran sebagai berikut.

\section{Bagi Para Siswa Peserta Ekstrakurikuler Karawitan}

Para siswa peserta ekstrakurikuler karawitan yang belum aktif dalam mengikuti kegiatan ekstrakurikuler karawitan hendaknya meningkatkan keaktifannya berpartisipasi dalam kegiatan ekstrakurikuler karawitan. Dengan kata lain, para siswa yang memang memilih untuk mengikuti kegiatan ekstrakurikuler karawitan harus mau secara totalitas mengikuti kegiatan ekstrakurikuler karawitan tersebut sehingga para siswa akan benar-benar mampu bermain alat musik karawitan dan memahami setiap makna atau nilai-nilai kearifan lokal yang terdapat di dalamnya.

\section{Bagi Guru Pelatih Ekstrakurikuler Karawitan}

Hendaknya guru pelatih ekstrakurikuler karawitan lebih meningkatkan lagi intensitas pemberian materi nilai-nilai kearifan lokal kepada para siswa sehingga siswa menjadi lebih memahami dan ikut melestarikan nilainilai kearifan lokal yang terdapat dalam karawitan sehingga dapat digunakan sebagai pedoman dalam kehidupan sehari-hari.

\section{Bagi Sekolah}

Hendaknya sekolah mempertahankan keberadaan ekstrakurikuler karawitan sehingga sekolah menjadi sebuah lembaga pendidikan yang tidak hanya berperan dalam mendidik siswa namun juga berperan ikut serta dalam pelestarian kebudayaan lokal dan nilai-nilai kearifan lokal. Sekolah juga dapat menyisipkan nilai-nilai kearifan lokal ke dalam kegiatan ekstrakurikuler seni budaya lokal yang lainnya. Selain itu, untuk menarik perhatian siswa agar mau mengikuti kegiatan ektrakurikuler karawitan maka sekolah dapat melakukan kolaborasi antara alat musik karawitan dengan alat musik lain. Alat musik tersebut misalnya alat musik modern yaitu organ, gitar, drum dan lainlain sehingga dapat dihasilkan suatu kolaborasi musik yang baru dan lebih menarik.

\section{Bagi Orang Tua Siswa}

Hendaknya orang tua siswa memberikan dukungan kepada anak-anaknya untuk berpartisipasi dalam kegiatan ekstrakurikuler karawitan karena kegiatan ekstrakurikuler karawitan adalah kegiatan yang positif dan melalui kegiatan tersebut maka anak tidak hanya sekedar belajar alat musik tradisional semata namun juga belajar tentang nilai-nilai kearifan lokal yang terkandung di dalamnya. 
Citizenship Jurnal Pendidikan Pancasila dan Kewarganegaraan Vol 5 No 1 April 2017, hal 1-12 Avaliable online at : http://e-journal.unipma.ac.id/index.php/citizenship p-ISSN: 2302-433Xp e-ISSN 2579-5740

DAFTAR PUSTAKA

Bahari, N. 2014. Kritik Seni: Wacana, Apresiasi dan Kreasi. Yogjakarta: Pustaka Pelajar.

Bratawijaya, T. W. 1997. Mengungkap dan Mengenal Budaya Jawa. Jakarta: PT. Pradnya Paramita.

Bungin, Burhan. 2007. Penelitian Kualitatif: Komunikasi, Ekonomi, Kebijakan Publik, dan Ilmu Sosial Lainnya. Jakarta: Kencana Prenada Media Grup. 2009. Metodologi Penelitian Kuantitatif: Komunikasi, Ekonomi dan Kebijakan Publik Serta Ilmu-ilmu Sosial Lainnya. Jakarta: Kencana Prenada Media Grup.

Departemen Pendidikan Nasional. 2014. Kamus Besar Bahasa Indonesia Pusat Bahasa. Jakarta: Gramedia Pustaka Utama.

Fajarini, U. 2014. Peranan Kearifan Lokal Dalam Pendidikan Karakter. Jurnal Sosio Didaktika (Online), Volume 1, No. 2 (http://journal.uinjkt.ac.id/index.php/ SOSIOFITK/article/download/1225/ 1093 Diunduh 15 Maret 2016)

Heliarta, S. 2009. Seni Karawitan. Semarang: Aneka Ilmu.

Hendarto, S. dan Hastono. S. 2011. Organologi dan Akustika I \& II. Bandung: Lubuk Agung.

Karmadi, A. D. 2007. Budaya Lokal Sebagai Warisan Budaya Dan Upaya Pelestariannya. Makalah Disampaikan Pada Dialog Budaya Daerah Jawa Tengah Yang
Diselenggarakan Oleh Balai Pelestarian Sejarah Dan Nilai Tradisional Yogjakarta Bekerja Sama Dengan Dinas Pendidikan Dan Kebudayaan Propinsi Jawa Tengah, Semarang 8-9 Mei 2007. (http://kebudayaan.kemdikbud.go.id/ wpcontent/uploads/sites/37/2014/11/ Budaya_Lokal.pdf Diunduh pada 14 Maret 2016)

Kodrat, Ki Harsono. 1982. GendingGending Karawitan Jawa Lengkap Slendro Pelog Jilid 1. Jakarta: Balai Pustaka.

Koentjaraningrat. 2009. Pengantar Ilmu Antropologi. Jakarta: Rineka Cipta.

Kompri. 2015. Manajemen Pendidikan: Komponen-komponen Elementer Kemajuan Sekolah. Yogjakarta: ArRuzz Media.

Lisbijanto, H. 2013. Ketoprak. Yogjakarta: Graha Ilmu. Graha Ilmu. . 2013. Ludruk. Yogjakarta: . 2013. Sekaten. Yogjakarta: Graha Ilmu. 2013. Wayang. Yogjakarta: Graha Ilmu.

Margono, S. 2010. Metode Penelitian Pendidikan. Jakarta: PT. Rineka Cipta.

Moloeng, L. J. 2012. Metode Penelitian Kualitatif. Bandung: Remaja Rosdakarya.

Noor, R. M. 2012. The HiddenCurriculum: Membangun Karakter Melalui

10 | Pryo Sularso, Yuli Maria Upaya Pelestarian Kearifan Lokal Melalui Ekstrakurikuler Karawitan di SMP Negeri 1 Jiwan Tahun 2016 
Citizenship Jurnal Pendidikan Pancasila dan Kewarganegaraan Vol 5 No 1 April 2017, hal 1-12 Avaliable online at : http://e-journal.unipma.ac.id/index.php/citizenship p-ISSN: 2302-433Xp e-ISSN 2579-5740

Kegiatan Ekstrakurikuler.

Yogjakarta: Insan Madani.

Peraturan Menteri Pendidikan Nasional Republik Indonesia Nomor 22 Tahun 2006 Tentang Standar Isi Untuk Satuan Pendidikan Dasar Dan Menengah (http://sdm.data.kemdikbud.go.id/SN P/dokumen/Permendiknas\%20No\%2 022\%20Tahun\%202006.pdf

Diunduh 14 Maret 2016)

Pramono, A. 2010. Implementasi Kearifan Lokal Dalam Pendidikan Karakter Di Pendidikan Dasar: Studi Karakter Nasionalisme Tokoh Karna Dalam Tripama Karangan KGPAA Mangkunegara IV, Jurnal Pendidikan Karakter, Vol.10, No.4, H.64-74.

(http://ejournal.ikippgrimadiun.ac.id/ sites/default/files/3.4_agung\%20pra mono implementasi\%20local\%20wi sdom\%20dlm\%20pendidikan\%20kar akter\%20di\%20dikdas.pdf Diunduh pada 14 Maret 2016)

Rahyono, F. X. 2015. Kearifan Budaya Dalam Kata Edisi Revisi. Jakarta: Wedatama Widya Sastra.

Ratna, N. K. 2010. Metodologi Penelitian: Kajian Budaya dan Ilmu Sosial Humaniora Pada Umumnya. Yogjakarta: Pustaka Pelajar.

Sabda. 2008. Wirid Purba Jati: Mengenali Jati Diri; Hakekat Neng, Ning, Nung, Nang. Artikel (https://sabdalangit.wordpress.com/2 008/12/22/mengenali-jatidirihakekat-neng-ning-nung-nang/ Diunduh pada 13 Maret 2016)
Sartini, N. W. 2009. Menggali Nilai Kearifan Lokal Budaya Jawa Lewat Ungkapan (Bebasan, Saloka dan Paribasa). Jurnal Ilmiah Bahasa dan Sastra (Online), Volume V, No. 1, (http://repository.usu.ac.id/bitstream/ 123456789/17541/1/logapr20095\%2 0\%284\%29.pdf Diunduh 14 Maret 2016)

Sartini. 2004. Menggali Kearifan Lokal Nusantara Sebuah Kajian Filsafati. Jurnal Filsafat (Online), Jilid 37, No.2 (http://dgi-indonesia.com/wpcontent/uploads/2009/02/menggalike arifanlokalnusantara1.pdf Diunduh 15 Maret 2016)

Satori, D. dan Komariah, A. 2012. Metode Penelitian Kualitatif. Bandung: Alfabeta.

Sedyawati, E. 2006. Budaya Indonesia: Kajian Arkeologi, Seni, dan Sejarah. Jakarta: PT Raja Grafindo Persada.

Soedarsono, dkk. 1985. Gamelan, Drama Tari, dan Komedi Jawa. Diterbitkan oleh Proyek Penelitian dan Pengkajian Kebudayaan Nusantara (Javanologi) Direktorat Jenderal Kebudayaan Departemen Pendidikan dan Kebudayaan 1984/1985.

Soyomukti, N. 2010. Pengantar Sosiologi: Dasar Analisis, Teori, \& Pendekatan Menuju Analisis Masalah-Masalah Sosial, Perubahan Sosial, \& Kajiankajian Strategis. Jogjakarta: Ar-ruzz Media.

Sugiyono. 2010. Metode Penelitian Pendidikan: Pendekatan Kuantitatif, Kualitatif dan $R \& D$. Bandung: Alfabeta. 
Citizenship Jurnal Pendidikan Pancasila dan Kewarganegaraan Vol 5 No 1 April 2017, hal 1-12 Avaliable online at : http://e-journal.unipma.ac.id/index.php/citizenship p-ISSN: 2302-433Xp e-ISSN 2579-5740

2015. Memahami Penelitian

Kualitatif. Bandung: Alfabeta.

Sukinah. 2011. Seni Gamelan Jawa Sebagai Alternatif Pendidikan Karakter Bagi Anak Autis Di Sekolah Luar Biasa. Makalah Proceeding disajikan dalam Seminar Nasional Revitalisasi Nilainilai Budaya Jawa dalam

Membentuk Generasi yang

Berkarakter, Fakultas Ilmu Pendidikan Universitas Negeri Yogjakarta, Yogjakarta, 23 Juli 2011.

(http://staff.uny.ac.id/sites/default/fil es/scan0001_3.pdf Diunduh pada 14 Maret 2016)

Sukmadinata, N. S. 2012. Metode Penelitian Pendidikan. Bandung: PT. Remaja Rosdakarya.

Syahroni dan Somantri, T. 2010. Pandai Karawitan. Bandung: Andira Putra.

Tarakanita, I. dan Cahyono, M.Y. M. 2013. Komitmen Identitas Etnik Dalam Kaitannya dengan Eksistensi Budaya Lokal. Jurnal Zenit (Online)

Volume 2, No. 2

(http://www.google.co.id/url?sa=t\&r $\mathrm{ct}=\mathrm{j} \& \mathrm{q}=\&$ esrc $=\mathrm{s} \&$ source $=\mathrm{web} \& \mathrm{~cd}=$ $1 \&$ ved=0ahUKEwjijHp28DNAhVMM48KHRBZAmEQ FggZMAA\&url=http\%3A\%2F\%2F
majour.maranatha.edu\%2Findex.php \%2Fzenit $\% 2$ Farticle $\% 2$ Fdownload $\%$ 2F1298\%2F1361\&usg=AFQjCNE9J wgFJMaBK8Zlet8IG-d7rVkyKg Diunduh 14 Maret 2016)

UU No. 20 Tahun 2003 Tentang Sistem Pendidikan Nasional (http://kemenag.go.id/file/dokumen/ UU2003.pdf, Diunduh 14 Maret 2016)

Wagiran. 2012. Pengembangan Karakter BERBASIS Kearifan Lokal Hamemayu Hayuning Bawana: Identifikasi Nilai-nilai Karakter BERBASIS Budaya. Jurnal pendidikan Karakter (Online) Tahun II, No. 3 (http://www.google.com/url?sa=t\&rc $\mathrm{t}=\mathrm{j} \& \mathrm{q}=\&$ esrc $=\mathrm{s} \&$ source $=$ web\& $\mathrm{cd}=2$ \&ved=0ahUKEwiXw j54MDNAhX IM48KHWO9AJ8QFggjMAE\&url= http\%3A\%2F\%2Fjournal.uny.ac.id\% 2Findex.php\%2Fipka\%2Farticle\%2F download\%2F1249\%2F1050\&usg= AFQjCNG7f3K-

jEwIHewmC2TLYoFwvJJg_w

Diunduh 14 Maret 2016)

Wibowo, A. dan Gunawan. 2015.

Pendidikan Karakter Berbasis Kearifan Lokal Di Sekolah: Konsep, Strategi dan Implementasi. Yogjakarta: Pustaka Pelajar. 